\title{
Keeping it Clean: Controlling Mildew ${ }^{1}$
}

Mary N. Harrison ${ }^{2}$

Mildew is a mold that can grow and cause damage to your health and home. You should be concerned about mildew because it makes respiratory problems, like asthma, worse.

- Mildew is easy to recognize. It has a musty odor and black fuzzy discoloration. It can also be brownish or reddish in color.

- Mildew grows best in moist warm air, like we have in Florida.

- It grows well on damp clothing, in bathrooms and other places where there is moisture.

\section{To keep mildew from growing:}

- Clean showers/tub weekly or more often so mildew cannot grow on soap scum and moisture.

- Dry off the shower walls after a shower so water will not cling to the walls.

- Hang damp towels where air will circulate so that they will dry quickly.

- Do not let damp or wet clothes lay around. Dry them before putting them in the clothes hamper.
- Cut the hem off of the plastic shower curtain so drops of water will drip off. Stretch the shower curtain out so it will dry instead of sticking together.

- Take shorter showers and use cooler water. Steam wets the ceiling and the walls.

- Open closet doors so air will circulate. Do not hang soiled clothes in closets. Dirt and soil attract bugs.

- Remove food stains from furniture as quickly as possible.

- Use fans to circulate the air.

- Keep shoes dry and clean.

\section{If you have mildew look for ways to get rid of it}

- For clothes with mildew stains use 2 tablespoons of liquid chlorine bleach with 1 quart of water. Sponge or soak for 5 to 15 minutes, then rinse. Or for a washer load of clothes, add 1 cup of chlorine bleach in the wash water.

1. This document is FCS5232-11, one of a series of the Family Youth and Community Sciences Department, Florida Cooperative Extension Service, Institute of Food and Agricultural Sciences, University of Florida. Original publication date June 2002. Revised November 2005. Visit the EDIS Web Site at http://edis.ifas.ufl.edu.

2. Mary N. Harrison, professor, Department of Family, Youth and Community Sciences, Cooperative Extension Service, Institute of Food and Agricultural Sciences, University of Florida, Gainesville, 32611.

The Institute of Food and Agricultural Sciences (IFAS) is an Equal Opportunity Institution authorized to provide research, educational information and other services only to individuals and institutions that function with non-discrimination with respect to race, creed, color, religion, age, disability, sex, sexual orientation, marital status, national origin, political opinions or affiliations. U.S. Department of Agriculture, Cooperative Extension Service, University of Florida, IFAS, Florida A. \& M. University Cooperative Extension Program, and Boards of County Commissioners Cooperating. Larry Arrington, Dean 
- For clothing that chlorine bleach will damage

use non-chlorine bleach and soak the garment(s) for 30 minutes or longer, then rinse.

- Clean the shower with chlorine bleach. (Open the window for ventilation when using chlorine bleach. Do not mix chlorine bleach with any other cleaning product.)

- Place musty bedding in the sunshine for several hours. If mildew remains, sponge with a cloth moistened with 1 cup rubbing alcohol and 1-cup water, then dry thoroughly. 